УДК 343.614

\title{
MAKING A SUICIDE ATTEMPT AS AN AGGRAVATING FEATURE IN THE LAW OF THE REPUBLIC OF POLAND (ARTICLE 190A $§ 3,207 \S 3$ AND 352 § 3 OF THE POLISH CRIMINAL CODE)
}

\author{
A. Michalska-Warias \\ Maria Curie-Sklodowska University in Lublin, \\ Pl. Marii Curie-Skłodowskiej 5, 20-031 Lublin, Poland, \\ e-mail:anetam11@op.pl
}

The Author analyses those offences from the Polish criminal code which have aggravated types connected with the victim's suicide attempt resulting from the offender's initial forbidden act. The interpretation problems connected with these types of offences are discussed. They are connected with possible controversies of attributing the offence to the offender in those cases in which his behaviour was one of a few causes of the victim's decision to kill him/herself. The proper solution is to accept the offender responsibility when his maltreatment or stalking of the victim was the key factor in the victim's decision making process. The paper also discusses the controversial issue of the mens rea of aggravated types characterised by the victim's suicide attempt (which has to be serious, but does not have to be successful). This is connected with the construction of offences aggravated by their consequences. While for most of such offences it is obvious that the consequences need to be unintended (if they are intended, the offender commits another offence, e. g. murder), this can be questioned in the discussed case, since it might lead to lack of responsibility for intentionally making somebody commit suicide (since suicide is not an offence) or to the responsibility for murder, which in the case of victims who are not specially vulnerable, may be also controversial. Therefore the Author proposes interpretation accepting the application of the discussed aggravated types to both unintentional and intentional causation of the victim's suicide attempt.

Keywords: suicide; aggravated stalking; aggravated maltreatment; aggravating features.

DOI: http://dx.doi.org/10.30970/vla.2018.67.221

There are three offences in the Polish criminal law system in whose case the aggravated type is connected with the fact that the perpetrator's behaviour causes the victim's suicide attempt. The first one historically is the offence of maltreatment (known since the introduction of the Criminal Code of 1969) and described by art. 207 of the now binding Criminal Code of 1997. There are two basic types of that offence. The perpetrator guilty of the maltreatment of a closely related or dependent person (Art. 207 $\S 1$ CC) faces the punishment of imprisonment from 3 months to 5 years and the perpetrator guilty of maltreatment of a helpless person (Art. 207 § 1a CC) - the punishment from 6 months to 8 years. There are two aggravated types of these offences. The first one (Art. $207 \S 3 \mathrm{CC}$ ) is characterised by the fact that the perpetrator uses extreme cruelty towards the maltreated victim and this type is punished with imprisonment from 1 to 10 years. The features of the second aggravated type, described in Art. $207 \S 3 \mathrm{CC}$, are fulfilled when the maltreatment leads to the victim undertaking a suicide attempt. The punishment in such a case is imprisonment from 2 to 12 years.

The second offence in the analysed group, first introduced into the Polish criminal law system by the binding Criminal Code of 1997, is the misdemeanour of maltreating a

(C) Michalska-Warias A., 2018 
subordinate soldier, described by Art. 352 CC. Its construction is similar to that of Art. $207 \mathrm{CC}$. There are two aggravated types characterised by the perpetrator's extreme cruelty (Art. $352 \S 2 \mathrm{CC}$ ) or by causing the victim to attempt a suicide (Art. $352 \S 3 \mathrm{CC}$ ). The punishment is the same as in the case of the offence of maltreatment, i.e. imprisonment from 3 months to 5 years for the basic type of the offence and respectively imprisonment form 1 to 10 years and from 2 to 12 years for the aggravated types.

The third and last offence whose features comprise the suicide attempt as an aggravating element is described by Art. 190a CC. This provision was added in 2011 [see the statute from $25^{\text {th }}$ February, 2011 on the modification of the statute - Criminal Code, Journal of Laws of 2011, No 72, position 381], and it refers to two basic types of offences. The first one, described by Art. 190a $\S 1 \mathrm{CC}$ is known as stalking and it criminalises the persistent harassment of another person or a person closely related to him/her, thus causing the victim's justified fear or infringing on his/her privacy. Art. 190a $\S 2$ criminalises in turn the behaviour known as impersonating another person. It makes it a criminal act to impersonate another person and use that person's image or other personal data in order to cause material or personal damage. Both offences are punished with imprisonment from 1 month to 3 years and both are prosecuted only on the victim's motion. There is a common aggravated type referring to the above described offences - according to Art. 190a $\S 3$ CC if the victim of the acts described in $\S 1$ or 2 makes a suicide attempt as a result of the offender's behaviour, the offender faces the punishment of imprisonment from 1 to 10 years.

While the offence of stalking is in many ways similar to the offence of maltreatment, which makes it reasonable (or at least justifiable) to create similar aggravated types in both cases, the same cannot be said about the offence of impersonating another person which in practice refers mainly to situations happening in virtual reality. This solution has been already criticised by authors analysing Art. 190a $\S 2$ CC [14, p. 38]. The presence of such an aggravated type (Art. 190a $\S 3 \mathrm{CC}$ in connection with Art. 190a $\S 2 \mathrm{CC}$ ) is even more surprising if one realises that there are other offences in the Criminal Code which contain the element of maltreatment of the victim, yet the lawmaker has not created such aggravated types in their cases. This refers to the offences described by Art. 246 and 247 CC. Art. 247 $\S 1 \mathrm{CC}$ describes the basic type of the offence of maltreatment of a person who is legally deprived of liberty (e.g. a prisoner). There is only one aggravated type of this offence, described by Art. $247 \S 2 \mathrm{CC}$ and its features are fulfilled when the maltreatment is accompanied by extreme cruelty. Art. 246 refers to the maltreatment of a person by a public official or by a person executing his commands in order to enforce some testimony, explanations, information or statements. In the case of both offences it seems quite possible that the perpetrator's behaviour may lead to the victim's decision to commit suicide, yet no aggravated types of that kind have been constructed by the lawmaker. Therefore, it can be argued, that while Art. 246 and $247 \S 1$ or 2 CC exclude the application of Art. $207 \S 1$ or $2 \mathrm{CC}$ in the criminal qualification, the real concurrence of provisions between Art. 246/247 $\S 1$ or $2 \mathrm{CC}$ and Art. $207 \S 3 \mathrm{CC}$ takes place in those cases in which the maltreatment led to the suicide attempt of the victim [11, p. 91-91; 17, p. 851].

One should also note the lack of consistency of the legal sanctions for the aggravated types referring to the victim's suicide attempt. While for the first two offences described earlier (i.e. Art. $207 \S 3$ and Art. $352 \S 3$ CC) the punishment is imprisonment from 2 to 12 years, if the suicide attempt was induced by the behaviour described by Art. 190a $\S 1$ or 2 CC, then the maximum punishment is 10 years of imprisonment. Since in all these cases it is the life and health of the victim which become the main protected values, the punishment should not differ, even if the initial offences are of different weight which is reflected by their punishments [15, p. 472]. 
All the above described inconsistencies - the diversified punishments for causing similar results, the lack of aggravated types characterised by the victim's suicide attempt in the case of maltreatment described in Art. 246 and 247 and the presence of such a type in the case of the offence of impersonating another person, may lead to the conclusion, that one of the possible solutions could be the creation of a new general offence, making it possible to punish more severely the perpetrator of any intentional offence if his behaviour caused the victim's suicide attempt (of course, if at least negligence would characterise the mens rea referring to that consequence of the offender's behaviour).

There is no doubt in the criminal law literature that in order to fulfil the aggravating feature in the form of causing the victim to make a suicide attempt, there needs to be a causal link between the forbidden act described in the basic type of a given offence and the victim's attempt to take his/her own life. It is also commonly accepted that the maltreatment or stalking does not need to be the only cause of the victim's decision, yet this should be the decisive factor. This is connected with the knowledge of human psyche. As it is stressed in literature, it is rarely so that there is only one reason why somebody decided to kill himself. Usually the suicide results from many factors which intermingle and as long as the offender's behaviour was the key factor in the victim's decision to end his/her life (in other words, as long as there would have been no suicide attempt without the maltreatment or stalking), the offender should be charged with committing the proper aggravated type of maltreatment or stalking [9, p. 991; 12, p. 9].

As can be easily inferred from the expression used in the discussed provisions, the only element which is required to ascribe to the offender the aggravated type is the undertaking of a suicide attempt by the victim, regardless of the actual outcome of the attempt. The victim does not need to successfully take his/her own life. It is enough that the attempt has taken place, as long as the attempt was $\mathrm{w}$ serious one, i.e. the victim of the maltreatment was not faking the suicide.This opinion is shared by most criminal law scholars [see e. g.: 8, p. 869; 9, p. 991; 5, p. 958; 10, p. 1307]. There can be some doubts about the state of mind of the victim referring to the suicide he/she is committing. Undoubtedly the requirements of the aggravated types are met when the victim sincerely wants to kill him/herself, yet it can be argued that these requirements are met also when the victims makes a potentially dangerous suicide attempt, hoping that somebody will manage to rescue him/her at the last moment, yet, accepting also the possibility of not receiving such help and dying [more on this issue: 2, p. 170-177]. This was stressed by the Supreme Court in a decision of $5^{\text {th }}$ March 2014, in which the court stated that the «victim's decision to kill himself, which is reflected in the attempt to commit suicide as a consequence of maltreatment (Art. $207 \S 3 \mathrm{CC}$ ), means at least the awareness of the possibility to end one's own life due to a given behaviour and the acceptance of one's own death» [4].

There are some controversies in literature referring to the proper interpretation of those cases in which the victim did intend to commit suicide but chose means that could not cause his/her death, e.g. used a substance that was not poisonous at all or was not poisonous enough to cause death. Some authors claim that in such cases the perpetrator of maltreatment or stalking cannot be charged with the discussed aggravated types of these offences, since no danger for the victim's life was present $[18$, p. 58-59; 11, p. 96]. Yet, it could also be argued that it is the awareness of the victim and his/her state of mind that matter and not the actual outcome of the suicide attempt. If one associates the higher punishment for causing a suicide attempt not only with the creation of an actual danger for the life and health of the victim but also with the increased intensity of the maltreatment or stalking preceding it - if the offender is to be responsible for the suicide attempt he should foresee or at least be able to foresee such an outcome of his acts, and 
this is possible only in those cases in which the behaviour preceding the suicide attempt was characterised by such intensity that the victim's extreme reaction might have been foreseen - then it could be argued that the actual chances of the attempt to be successful are important only at the stage of imposing the punishment and not at the state of establishing the proper legal qualification. This is especially visible in those cases in which the victim e.g. swallowed an insufficient portion of some kind of poison, thus causing some health problems but not the expected death [12, p. 8].

The most important and most controversial problem connected with the interpretation of the discussed aggravated types of offences refers to their mens rea. This is connected with the fact that all these types of offences constitute the so called offences aggravated by their consequences. Such a construction is quite often in the Polish Criminal Code and is basically based on the pattern in which the basic type of an offence is intentional (or unintentional), while the consequences which may result from the behaviour described in the basic type of the offence are not intended by the perpetrator, yet it can be proven that he has foreseen them or could have foreseen them, which means that the consequences are unintentional. This type of the mens rea is described by Art. 9 $\S 3 \mathrm{CC}$, according to which the offender faces more severe punishment which, according to the statute, depends on the consequence of a forbidden act, if he has foreseen or could have foreseen that consequence. Most of the authors agree that the consequence of such offences must be unintended by the offender, and in those cases in which the offender intends to cause the forbidden consequence, he should be held responsible not for the aggravated type of that offence but for the intentional act he committed. Generally, the opinion that the only possible combination making it acceptable to apply the provisions describing a type aggravated by the consequences is the combination of the initial intended/unintended act with unintentional consequences is expressed by many authors $[19$, p. $41 ; 7$, p. $113 ; 13$, p. $284 ; 1$, p. $78 ; 16$, p. 162; 3, p. 43-44]. For example, if the offender sets fire intentionally and unintentionally kills somebody in this way, he should be held responsible for the offence of intentionally causing a catastrophe with the consequence in the form of somebody's death - Art. $163 \S 3 \mathrm{CC}$, yet, if the fire was set in order to kill somebody, the perpetrator should be charged with murder - Art. 148 CC, this provision being in real concurrence with the provision referring to the causing of a catastrophe in its basic form, i.e. Art. $163 \S 1 \mathrm{CC}$. This difference is important, since the punishment for causing a catastrophe and thus causing a further, unintentional result in the form of somebody's death is punished with imprisonment up to 12 years, while the maximum punishment for murder is life imprisonment.

While there is no doubt that art. $207 \S 3,532 \S 3$ and 190a $\S 3$ CC refer first of all to situations in which the suicide attempt was not intended by the offender, i.e. to unintentional causing of such an attempt, there are controversies referring to the proper legal qualification in such cases in which the offender wanted to make the victim commit suicide or was aware of such a possibility and accepted it, i.e. caused the suicide attempt intentionally.

For those authors, and they seem to be the majority, who do not accept the possibility of causing the consequence intentionally if the construction of a type aggravated by its consequences is to be applied in the legal qualification, such cases do not fall under the discussed provisions. Since, for criminal policy reasons, it would seem absurd to assume that the perpetrator would then not be held responsible for the intended consequence of his forbidden act, it is suggested that such offenders should be found guilty of murder $[16$, p. $162 ; 15$, p. 84-85]. It seems that this solution could easily be accepted in those cases in which the victim is of special vulnerability (a child or an insane person), since in such cases the victim could be treated as a tool in the hands of 
the offender. This is, however, much more problematic in the case of other victims, since if they cannot be treated as tools in the hands of the offender - it is difficult to assume that it is the offender who performed the actus reus of the offence of murder (technically, what he does cannot be described as killing another person).

The solution here is to accept the possibility of applying the provision describing the aggravated type also in those cases in which the consequence of the initial offence was intended by the offender, of course, only as long as there is no intentional offence in the Criminal Code which better describes the actus reus and mens rea of the committed act. The existence of aggravated types in whose case the consequence of the initial act of the offender can be intentional is accepted in literature by some authors [20, p. 168; 6, p. 73; 12 , p. $13 ; 18$, p. 84-85]. This seems to be the case for the discussed provisions. Committing suicide is itself an act irrelevant for the criminal law, therefore intentionally causing the victim's decision to commit suicide does not constitute a basic type of offence (unless, of course, the possibility to treat it as murder is accepted). An additional argument that could be brought forward is the application of the logical method of interpretation a minori ad maius - according to this, if something less is forbidden, than something more is forbidden as well. This is the case here: since it is forbidden to unintentionally cause the suicide attempt of another person, it must be also forbidden to do so intentionally.

If one looks at conviction statistics for the discussed aggravated offences, it turns out that it is the offence of maltreatment with the consequence in the form of the victim's suicide attempt that happens most frequently. Nonetheless, such offences are not too common anyway, e.g. while in 2016 there were altogether 10.883 persons found guilty of the offence of maltreatment, only 32 of them committed the aggravated type of maltreatment described in Art. $207 \S 3$ CC (so such convictions constituted only $0,3 \%$ of all convictions for maltreatment). Generally, the number of persons found guilty of the offence from Art. $207 \S 3$ CC in the period 2010-2016 was as follows: in 2010 there were 57 persons convicted, in $2011-43$, in 2012 - 41, in $2013-56$, in $2014-36$, in $2015-58$ and in $2016-32$ persons. The average number of such convictions for the discussed period is then 46 per year. The numbers for the aggravated type of stalking described by Art. 190a $\S 3 \mathrm{CC}$ are statistically insignificant: in the period 2011-2012 it was only one conviction each year, there were 4 convictions both in 2014 and 2015 and 5 - in 2016 [the data can be found on the Polish Ministry of Justice web pages: https://isws.ms.gov.pl/pl/bazastatystyczna/opracowania-wieloletnie/ (access date: 10.05.2018)].

Concluding, it should be stressed that while the aggravated types of offences characterised by the consequence in the form of the victim's suicide attempt are very interesting from the theoretical point of view and there are some serious controversies connected with their interpretation, they do not seem to play such an important role in the criminal justice practice and - judging by the judicature concerning them - some of the most serious interpretation problems do not appear in practice, while those issues which do appear are dealt with quite adequately by the courts.

\section{Список використаних джерел}

1. Bojarski T. [and other] Kodeks karny. Komentarz. Warszawa, 2016.

2. Budyn-Kulik M. Glosa do postanowienia SN z dnia 5 marca 2014 r., IV KK 316/13 // Studia Iuridica Lublinensia. 2015. No 24.

3. Budyn-Kulik M. [and other]. Kodeks karny. Komentarz. Warszawa, 2015.

4. Filar M. [and other] Przestępstwa przeciwko wolności // Filar. M. Kodeks karny. Komentarz. Warszawa, 2016.

5. Giezek J. Kodeks karny. Część ogólna. Komentarz. Warszawa, 2012.

6. Grześkowiak A. Kodeks karny. Komentarz. Warszawa, 2015. 
7. Jodłowski J., Szewczyk M. Przestępstwa przeciwko rodzinie i opiece // Jodłowski J., Szewczyk M. Kodeks karny. Część szczególna. Tom II, Warszawa, 2017.

8. Konarska-Wrzosek V. Przestępstwa przeciwko rodzinie i opiece // Konarska-Wrzosek V. System prawa karnego, Tom 10, Przestępstwa przeciwko dobrom indywidualnym. Warszawa, 2016.

9. Kosonoga J. Przestępstwa przeciwko rodzinie i opiece // Kosonoga J. Kodeks karny. Komentarz. Warszawa, 2015.

10. Kozłowska-Kalisz P. Targnięcie się na własne życie - wybrane zagadnienia dogmatyczne // Kozłowska-Kalisz P. Samobójstwo. Warszawa, 2017.

11. Krajewski $R$. Targnięcie się na własne życie jako skutek przestępstwa znęcania // Prokuratura i Prawo. 2017. No. 4.

12. Królikowski M. Kodeks karny. Część ogólna. Komentarz. Tom I, Warszawa, 2017.

13. Lach A. Kradzież tożsamości // Prokuratura i Prawo. 2012. No 3.

14. Mozgawa M. Przestępstwa przeciwko wolności // Mozgawa M. System prawa karnego, Tom 10, Przestępstwa przeciwko dobrom indywidualnym. Warszawa, 2016.

15. Przesławski T. Kodeks karny. Komentarz. Warszawa, 2015.

16. Razowski T. Kodeks karny. Część szczególna. Komentarz. Warszawa, 2014.

17. Wasek A. Prawnokarna problematyka samobójstwa. Warszawa, 1983.

18. Wasek A., Kulik M. Kodeks karny. Komentarz. Warszawa, 2016.

19. Zoll A. Kodeks karny. Część ogólna, Komentarz. Warszawa, 2016.

\section{References}

1. Bojarski, T. (2016). In T. Bojarski (ed.), Kodeks karny. Komentarz. Warszawa.

2. Budyn-Kulik, M. (2015). Glosa do postanowienia SN z dnia 5 marca 2014 r., IV KK 316/13, Studia Iuridica Lublinensia No 24.

3. Budyn-Kulik, M. (2015). In M. Mozgawa (ed.). Kodeks karny. Komentarz. Warszawa

4. Filar, M. (2016). Przestępstwa przeciwko wolności. In M. Filar (ed.). Kodeks karny. Komentarz. Warszawa.

5. Giezek, J. (2012). In J. Giezek (ed.). Kodeks karny. Część ogólna. Komentarz. Warszawa.

6. Grześkowiak, A. (2015). In A. Grześkowiak, K. Wiak (eds.). Kodeks karny. Komentarz. Warszawa.

7. Jodłowski, J., Szewczyk, M. (2017). Przestępstwa przeciwko rodzinie i opiece. In W. Wróbel, A. Zoll (eds.). Kodeks karny. Część szczególna. Tom II, Warszawa.

8. Konarska-Wrzosek, V. (2016). Przestępstwa przeciwko rodzinie i opiece. In J. Warylewski (ed.) System prawa karnego, Tom 10, Przestepstwa przeciwko dobrom indywidualnym. Warszawa.

9. Kosonoga, J. (2015). Przestępstwa przeciwko rodzinie i opiece. In R. A. Stefański (ed.). Kodeks karny. Komentarz. Warszawa.

10. Kozłowska-Kalisz, P. (2014). Targnięcie się na własne życie - wybrane zagadnienia dogmatyczne. In M. Mozgawa (ed.). Samobójstwo. Warszawa.

11. Krajewski, R. (2017). Targnięcie się na własne życie jako skutek przestępstwa znęcania. Prokuratura i Prawo, No. 4.

12. Królikowski, M (2017). In M. Królikowski, R. Zawłocki (eds.), Kodeks karny. Część ogólna. Komentarz, Tom I, Warszawa.

13. Lach, A. (2012). Kradzież tożsamości. Prokuratura i Prawo, No 3.

14. Mozgawa, M. (2016), Przestępstwa przeciwko wolności. In J. Warylewski (ed.), System prawa karnego, Tom 10, Przestepstwa przeciwko dobrom indywidualnym. Warszawa.

15. Przesławski, T. (2015). In R. A. Stefański (ed.). Kodeks karny. Komentarz. Warszawa.

16. Razowski, T. (2014). In J. Giezek (ed.). Kodeks karny. Część szczególna. Komentarz. Warszawa.

17. Wąsek, A. (1983). Prawnokarna problematyka samobójstwa. Warszawa.

18. Wąsek, A., Kulik, M. (2016). In M. Filar (ed.). Kodeks karny. Komentarz. Warszawa.

19. Zoll, A. (2016). In W. Wróbel, A. Zoll (eds.). Kodeks karny. Część ogólna, Komentarz. Warszawa. 


\title{
СПРОБА САМОГУБСТВА ЯК КВАЛІФІКУЮЧА ОЗНАКА В ЗАКОНОДАВСТВІ РЕСПУБЛІКИ ПОЛЬЩА (Ч. 3 СТ. 190A, Ч. 3 СТ. 207 ТА Ч. 3 СТ. 352 КРИМІНАЛЬНОГО КОДЕКСУ РЕСПУБЛІКИ ПОЛЬЩА)
}

\author{
А. Міхальська-Варіас \\ Університет Марії Кюрі-Склодовської, \\ пл. М. Кюрі-Склодовської, 5, Люблін, Республіка Польща, 20-031, \\ e-mail:anetam11@op.pl
}

Проаналізовано ті злочини, передбачені Кримінальним кодексом Республіки Польща, які мають кваліфіковані склади, виділені за спробою самогубства потерпілого внаслідок попереднього суспільно небезпечного діяння суб'єкта злочину.

У польському кримінальному законодавстві $\epsilon$ три випадки, коли поведінка зловмисника призводить до спроби самогубства потерпілого. Перший історично пов'язаний із неналежним поводженням (відомий з часу прийняття Кримінального кодексу 1969 р.) і закріплений у ст. 207 зараз чинного Кримінального кодексу 1997 р.

Другим випадком в аналізованій групі злочинів, уперше запровадженим у польську кримінально-правову систему Кримінальним кодексом 1997 р., $є$ неналежне поводження 3 підлеглим солдатом, передбачене в ст. 352 КК РП. Третій і останній злочин, кваліфікований за ознакою спроби самогубства, закріплений у ст. 190а, якою КК РП був доповнений у 2011 р. Вона закріплює два основні склади злочину: переслідування (ч. 1 ст. 190а КК РП) та видання себе за іншу особу (ч. 2 ст. 190а КК РП). Спільною кваліфрікуючою ознакою для описаних складів злочину є, відповідно до ч. 3 ст. 190а КК РП, спроба самогубства потерпілого в результаті такої поведінки суб'єкта злочину.

Проаналізовано проблеми інтерпретації цих злочинів. Вони пов'язані з можливими суперечностями щодо приписування діяння суб'єкту злочину у тих випадках, коли його поведінка була однією з кількох причин прийняття потерпілим рішення позбавити себе життя. Правильне вирішення проблеми полягає у визнанні відповідальності суб'єкта злочину у тих випадках, коли його неналежне поводження чи переслідування потерпілого було ключовим чинником у процесі прийняття потерпілим зазначеного рішення.

У публікації також розглянуто суперечливу проблему суб'єктивної сторони каліфікованих складів злочину, які характеризуються спробою самогубства потерпілого (яка має бути реальною, але не обов'язково повинна бути успішною). Це пов'язано з конструкцією складів злочину, кваліфікованих за наслідками. Хоча для більшості таких складів злочину очевидно, що ставлення до суспільно небезпечних наслідків має бути необережним (якщо ставлення до суспільно небезпечних наслідків є умисним, має місце інший склад злочину, наприклад, умисне вбивство), це твердження може бути поставлене під сумнів в аналізованому випадку, оскільки така інтерпретація може призвести до відсутності кримінальної відповідальності за умисне доведення когось до самогубства (оскільки саме по собі самогубство не є злочином) або до кримінальної відповідальності за умисне вбивство, що у випадку з потерпілими, які не є особливо вразливими, також може бути спірним. Отже, автор пропонує тлумачення, яке допускає застосування аналізованих кваліфікованих складів злочину як у випадку необережного, так і у випадку умисного доведення потерпілого до спроби самогубства.

Ключові слова: самогубство; переслідування як ознака складу злочину; неналежне поводження як ознака складу злочину; кваліфікуючі ознаки. 